\title{
ТАТМЫН НУГЫН БУЛГЭМДЛИЙН БИОМАСС ЦАГ УУРААС ХАМААРЧ ӨӨРЧЛӨГДӨХ НЬ
}

\author{
Хосбаяр $\Psi^{1}$, Нарантуяа $H^{\prime}$ \\ ${ }^{1}$ ШУА, Ботаникийн хүрээлэн
}

\section{Хураангуй}

Татмын нугын малын бэлчээрт их ашиглагдсан үетэн-алаг өвст бүлгэмдэл дээр бид 2009 онд 1 га талбайг хүн, малын нөлөөнөөс хашиж хамгаалан, хашааны гаднах талбайд бүлгэмдлийн өөрчлөгдлийн, хашааны доторх талбайд түүний байгалийн аясаар нөхөн сэргэх судалгааны ажлыг эхлүүлсэн тэр үеэс бүлгэмдлийн биомассын судалгааг хийсэн болно. Судалгааны эхний жилүүдэд биомассын судалгааг зөвхөн хашааны гаднах талбайд мал бэлчээрлэлт, цаг уурын нөлөөнөөс хамааруулан судалж, харин хашсан талбайн бүлгэмдлийн ургамлыг нөхөн сэргэж, биологи хөгжил нь хэвийн явагдах нөхцлөөр хангаж, ургамал олон дахин хадах, хайчлахыг дааж чадах хүртэл нь амрааж, хашиж хамгаалаад 4 жил болсны дараах 2012 оноос бүлгэмдлийн биомассын судалгааг эхлүүлж хашааны доторх болон гаднах талбайд харьцуулсан судалгааг хийсэн үр дүнг энэ өгүүлэлд тусгав.

Судалгааны үр дүнгээс харахад үетэн-алаг өвст бүлгэмдлийн хашсан талбайн биомассыг оноор харьцуулахад 2012 онд 331.36 г/ м² $^{2} 2013$ онд 452,61 г м² болж, бүлгэмдлийн нийт биомасс 1,4 дахин нэмэгдсэн, харин хашааны гаднах бүлгэмдэл 2012 онд 400,07

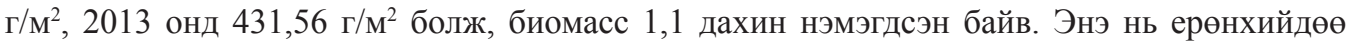
хур тунадсны хэмжээ олон жилийн дунджаас 2012 онд 48,6 мм, 2013 онд 68,8 мм-ээр их тунадас унасан ба агаарын температурын хувьд 2012 онд олон жилийн дунджаас -1,2 $\mathrm{C}^{0}, 2013$ онд $-0,2 \mathrm{C}^{0}$-ээр хүйтэрч сэрүүссэнтэй холбоотой юм. Татмын нуга нь ус чийгийн хангамж ихтэй, илүүдэл устай нөхцөл учраас биомассын өөрчлөлтөнд хур тунадаснаас илүү агаарын температур тэргүүн зэргийн нөлөөлөх хүчин зүйл болж байна. Харин хашааны гаднах бүлгэмдлийн биомассыг хашсан бүлгэмдлийн биомасстай харьцуулахад 1,2 дахин бага биомасс бүрдүүлсэн байв. Өөрөөр хэлбэл малын бэлчээрт их ашиглагдсан нугын бүлгэмдлийг хашиж хамгаалахад бүлгэмдлийн бүтэц бүрэлдэхүүн сайжирч, биомасс нэмэгдэх бичил орчин бүрддэг байна.

Татмын нугын бүлгэмдлийн биомассын хэмжээ, цаг уурын үзүүлэлт хоорондын корряляцийг бодоход агаарын температураас $(\mathrm{R}=0.816)$ шууд, хур тунадаснаас $(\mathrm{R}=0.47772)$ сул хамаарч байв.

Tүлхүур үг. Татмын нуга, ургамал бүлгэмдэл, биомасс, ияаг уур, мал бэлчээрлэлт,

\section{ОРШИЛ}

Биомасс гэдэг нь ургамлын тухайн жил бий болгосон назрын дээрх ногоон массын хэмжээг хэлнэ. Татмын нуга нь манай орны хувьд хадлан, бэлчээрийн үндсэн бааз учраас мал бэлчээрлэлтийн нөлөөнд илүу автдаг нутаг юм. Манай орон нүүдлийн мал аж ахуйтай байгалийн бэлчээртэй нутаг бөгөөд 2013 оны байдлаар 45 сая мал тоологдсон [7] бөгөөд нийт бэлчээр нутгийн 70 гаруй хувь нь ямар нэг хэмжээгээр доройтсон судалгааны үр бий [9]. Аливаа ургамалжлын биобүтээмжинд хүний хүчин зүйлсийн нөлөөнөөс гадна байгалийн хүчин зүйлс голлох нөлөөллийг 
үзүүлдэг.

Монгол орны агаарын жилийн дундаж температур сүүлийн 60 жилд 2.1 градусаар дулаарсан. Агаарын температур 26 градусаас давж халсан өдрийн тоо ялангуяа ургамлын вегетацийн хугацаанд нэлээд олширч улмаар хуурай үеийн үргэлжлэх хугацаа 20 хувиар нэмэгдсэн болохыг судлаачид тогтоожээ [2]. Иймд эдгээр хүчин зүйлсийн хэт нөлөөлөл ургамалжил доройтох, талхлагдах үндсэн шалтгаан болж, улмаар энэ нь даамжирч цөлжилтөнд ч хүргэх аюултай тул ургамалжлын өөрчлөгдлийг тогтмол хянах, биомассаар үнэлэх, ашиглалтыг тодорхой түвшинд зохицуулах шаардлагатай юм.

Судалгааны зорилго: Татмын нугын Үетэн-алаг өвст бүлгэмдлийн биомассын хөдлөлзүйг судлахад оршино.

Судалгааны объект: Татмын нугын Үетэн-алаг өвст бүлгэмдэл нь Төв аймгийн Мөнгөнморьт сумын нутагт д.т.д. 1439 м өндөрт, ХӨ $48^{0} 11^{\mathrm{I}} 11.0^{\mathrm{II}}$, ЗУ $108^{0} 26^{\mathrm{I}} 50.4^{\mathrm{II}}$ солбилцол дээр Баруун Бүрхийн голын

\section{СУДАЛГААНЫ ҮР ДҮН}

Судалгаа явуулсан хугацааны цаг уур: Ургамлын нөхөн сэргэх, хөгжлийн үе шат гүйцэх, биомасс бүрэлдүүлэх үйл ажиллагаа нь тухайн жилийн байгаль цаг уурын онцлогоос ихээхэн хамаардаг тул бид судалгаа явуулсан хугацааны цаг уурын (агаарын дундаж температур, хур тунадас) жилийн болон олон жилийн дундаж мэдээг Мөнгөнморьт харуулын станцын мэдээнд тулгуурлан боловсруулав.

Мөнгөнморьт харуулын станцын мэдээгээр хур тундасны олон жилийн (2000-2013) дундаж 267.0 мм, агаарын дундаж температур $-2.7{ }^{\circ} \mathrm{C}$ байв.

Бидний судалгаа явуулсан 20092013 онуудад нийт хур тунадас 123.5 мм, хөндийд тархана. Баруун Бүрхийн гол нь баруун талаараа намаг ихтэй, голын эхээр айлуудын хаваржаа, намаржаа, голын адгаар айлуудын зуслан байрладаг. Жилийн өвлөөс бусад улиралд малын бэлчээрт ашигладаг. Гүний болон гадаргын усаар тэжээгддэг $[8,10]$.

Судалгааны аргазүй: Татмын нугын бүлгэмдэлд 50х50 см² $^{2}$ талбайгаас ургамал ургалтын хугацаанд сар бүр 10, 10 хоногийн давтамжтай 3 давталттайгаар, хашсан талбайд сард 1 удаа, хашааны гаднах талбайд 3 давталттайгаар ургацын дээжийг ургамлын зүйлээр ялган газрын хөрсийг ширгүүлэн хайчлан авч, агаарын хуурай жинг тодорхойлов. Ингэхдээ түүний чанарыг үнэлэх үүднээс ургамлын аж ахуйн бүлгээр ангилан тус тусад тооцоолов [12].

Цуглуулсан материалын хэмжээ. 2012-2013 онд 6, 7, 8-р саруудад Татмын нугын Үетэн-алаг өвст бүлгэмдлийн хашсан болон хашааны гаднах бүлгэмдлээс биомассын 2016 ш дээжийг цуглуулж, статистик боловсруулалт хийсэн болно.

жилийн дундаж агаарын температур -15 ${ }^{0} \mathrm{C}$, нэгдүгээр сарын $-24.6{ }^{\circ} \mathrm{C}, 7-\mathrm{p}$ сарынх $15.7{ }^{\circ} \mathrm{C}$ байв. Сүүлийн таван жилийн цаг уурын мэдээнээс харахад хамгийн хүйтэн 1-р сар таван жилийн (2009-2013) дунджаас давж хүйтэрч, 7-p сарын агаарын дундаж температур олон жилийн дунджийн түвшинд байгаа нь агаарын температур жил ирэх бүр буурч, сэрүүсч байгааг харуулж байна (Зураг 1).

Зургаас харахад судалгаa явуулсан жилүүдийн ургамал ургалтын хугацаанд унасан хур тунадас, агаарын дундаж температур олон жилийн дунджаас давж байгаа нь ургамлын биомасс бүрэлдэхэд сөрөг нөлөө үзүҮлж байна. 


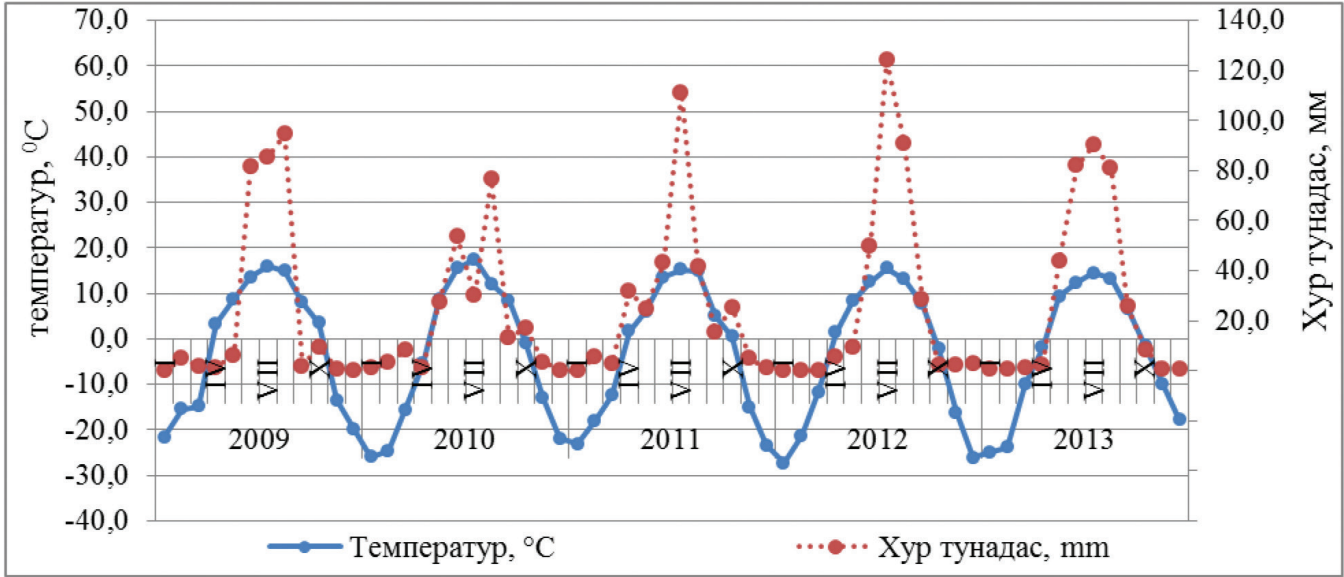

Зураг 1. 2009-2013 оны сарын агаарын дундаж температур, хур тунадасны хувиарилагдсан байдал (Мөнгөнморьт харуул станцьын мэдээгээр)

Татмын нугын бүлгэмдлийн биомассын хөдлөлзүй: 2012-2013 онд Татмын нугын үетэн-алаг өвст бүлгэмдлийн хашиж хамгаалсан бүлгэмдэл 2012 онд 331,6 г/м², хашааны гаднах мал тогтмол бэлчээрлэдэг бүлгэмдэл $\quad 400,07 \quad \Gamma / \mathrm{M}^{2}$ биомассыг бүрдүүлж, хашсан бүлгэмдэлд биомассын хэмжээ 1,2 дахин буурсан, харин 2013 онд хашааны гаднах бүлгэмдэл

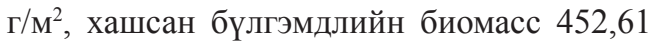
$\mathrm{M}^{2}$ болж хашааны гаднах бүлгэмдлийнхээс $(431,56) \quad 1,2$ дахин илүҮ биомассыг бүрдүүлсэн байв. Хашсан бүлгэмдлийн биомасс эхний хугацаанд багассан нь 2012 онд хашааны гаднах талбайд 3 давталттай, хашсан бүлгэмдэлд 2 давталттайгаар биомассын дээж авсан тул давталтын тооны зөрүүгээс болсон байх магадлал өндөр юм. Ерөнхийдөө хашсан бүлгэмдлийн

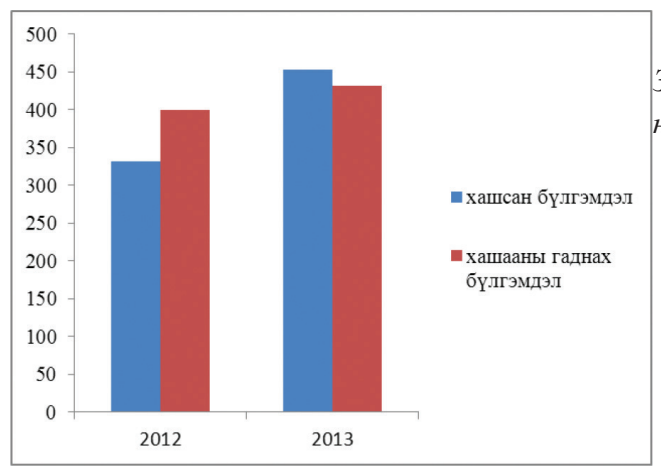

биомасс 1,2-1,4 дахин нэмэгдэж байгаа нь мал бэлчээрлэлтийн нөлөөгүй болгож хамгаалсантай холбоотой бөгөөд хашиж хамгаалах нь бүлгэмдлийн биомассыг нэмэгдүүлэх, ургамлын гарцыг сайжруулах гол хүчин зүйл болж буйн илэрхийлэл болно. Харин он оноор харьцуулвал 2013 онд бүлгэмдлийн биомасс хашсан болон хашааны гаднах аль ч бүлгэмдэлд нэмэгдэж байгаа нь (Зураг 2) тухайн жилд унасан хур тунадасны хэмжээ олон жилийн дунджаас 68,8 мм-ээр их, чийгийн хангамж сайтай байсантай холбоотой. Хэдийгээр 2012 онд хур тунадас олон жилийн дунджаар 48,6 ммээр их унасан ч агаарын дундаж температур олон жилийн дунджаас -1,2 хэмээр буурч сэрүүссэн нь биомасс бүрдэлтэнд сөрөг нөлөөллийг үзүүлсэн байна.

Зураг 2. Татмын үетэн-алаг өвст бүлгэмдлийн нийт биомасс 
Бүлгэмдлийн биомассын чанарыг үнэлэх зорилгоор түүний хэд хичнээн хувийг ямар ургамал бүрдүүлж буйг хувиар илэрхийлэх нь малд тохиромжтой, бэлчээрийн чанар өндөртэй ургамлын бүрдэлтийг тодорхойлох ач холбогдолтой. Бүлгэмдлийн биомассыг ургамлын аж ахуйн бүлгээр ангилан үзвэл хашиж хамгаалсан бүлгэмдлийн 2012-2013 онд бүрдүүлсэн нийт биомассын 19,5\%-ийг үетэн, улалж 7,1-16,4 \%-ийг, алаг өвс 22,2-42,4 \%-ийг бүрдүүлж харин шарилж 7,2-6,8\%-ийг харин хашааны гаднах бүлгэмдлийн нийт биомассын 21,7-17,2 \%-ийг үетэн, 10,415,5 \%-ийг улалж, 21,2-11,4 \%-ийг шарилж, 21,2-11,4 \%-ийг алаг өвс тус тус эзлэж байв. Үүнээс харахад хашиж хамгаалсан бүлгэмдэлд алаг өвс дийлэнх хувийг эзлэж байгаа ба үүнийг ургамлын зүйлээр ялгаж үзвэл малд сайн идэгддэг, тэжээлийн чанар сайтай Sanguisorba officinalis, Polygonium alopecuroides зэрэг ургамлын залуу бодгалиуд, Parnasia palustris, Halenia corniculata, Ranenculus radicans, Pedicularis flava зэрэг чийглэг орчныг шүтэн ургадаг зүйлүүдийнэзлэххувьихэссэнтэйхолбоотой

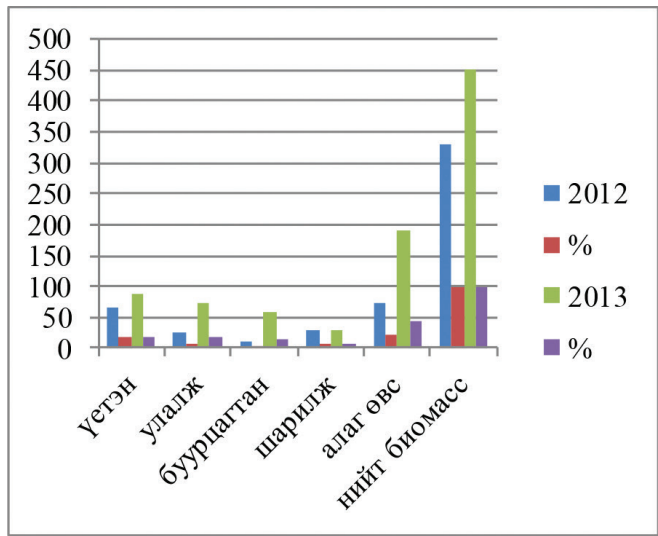

а. Хатиж хамгаалсан бүлгэмдлийн биомасс юм. Харин шарилжийн төрлийн ургамлууд буурсан байв. Хашааны гаднах мал тогтмол бэлчээрлэдэг бүлгэмэлд үетэн ургамлын эзлэх хувь харьцангуй их байгаа ба энэ нь хэдийгээр үетэн нь малд сайн идэгддэг хэдий ч хөгжлийн үе шатаасаа хамааран идэмж нь харилцан адилгүй болдог, улмаар зарим үетэний бэлчээрлэлтийн нөлөөг сайн тэсвэрлэдэг, ургал эрхтэнээр түрэн ургах чадвартай зэргээс шалтгаалдаг байна. Харин шарилж, улалжийн төрлийн ургамал 21 хүртэл хувийг бүрдүүлж байв (Зураг 3). Судалгааны дүнгээс харахад нугын бүлгэмдлийг хашиж хамгаалах нь бүлгэмдлийн биомассыг нэмэгдүүлэх, ургамлын гарцыг сайжруулах, талхлагдсан газрыг нөхөн ургадаг шарилж, нэг наст ургамлууд буурах, байгалийн нугын үндсэн ургамлууд сэргэн ургах бичил орчныг бүрдүүлж байгаа нь байгалийн аясаар нөхөн сэргээх нэгэн арга зам болж байна. Гэтэл байнгын мал бэлчээрлэж буй хашааны гаднах бүлгэмдэлд шарилжийн биомасс нэмэгдэж, түүний бүлгэмдэлд гүйцэтгэх үүрэг дээшилж ирдэг.

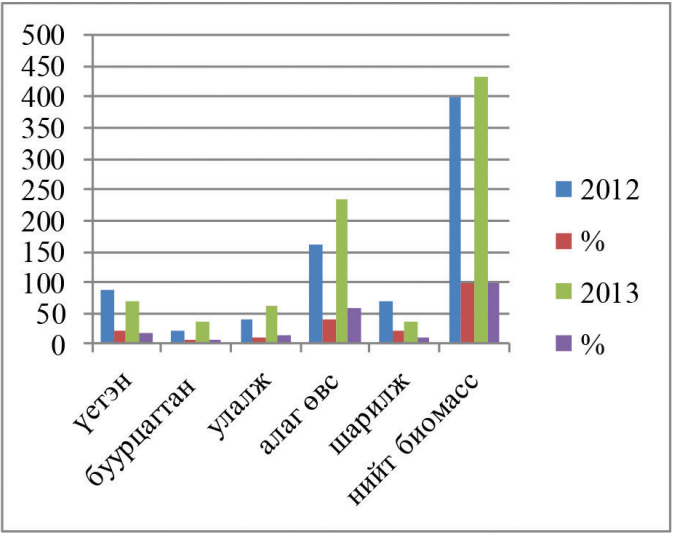

б. Хамаан гаднах бүлгэмдлийн биомасс

Зураг 3. Татмын нугын үетэн алаг өвст бүлгэмдлийн биомассын хөдлөлзуй (оноор)

2012 онд хашсан талбайн үетэн, улалж, буурцагтан, алаг өвсний биомасс 7-p сард, шарилжийнх 8-p сард дээд хэмжээндээ хүрч байхад, 2013 онд үетэн, буурцагтан, алаг өвс, шарилжийнх 7-p сард, харин улалжийнх 8-р сард зуны дээд хэмжээндээ хүрч хамгийн их ургацыг бүрдүүлж байна. Хашааны гаднах талбайд 2012 онд буурцагтан, алаг өвсний ургац 6-р сард, үетэн, шарилжийнх 8-р сард дээд 
хэмжээндээ хүрсэн бол улалжийн ургац 6, 7-p саруудад тогтмол байснаа 8-р сард буурсан, 2013 онд буурцагтан, алаг өвсний ургац 7-р сард, үетэн, улалж, шарилжийнх 8-р сард зуны дээд хэмжээндээ хүрч хамгийн их ургацыг бүрдүүлж байна (Хүснэгт 1).

Татмын нугын бүлгэмдлийг хашиж хамгаалахад зуны дээд ургац нь 7-р сард харин байнгын мал бэлчээрлэдэг хашааны гаднах талбайд 7, 8-р саруудад хуримтлагдсан байгаа нь ажиглагдав. Зуны дээд ургац бүрэлдэх 7-р сард бүлгэмдлийн хэмжээнд нийт зүйлийн $85-90 \%$ нь цэцэглэж, үрлэсэн байна. [11]. Тухайн бүлгэмдлийн зуны дээд ургац хуримтлагдах хугацаа нь бүлгэмдлийн цэцэглэлт болон үрлэлтийн үетэй давхцаж байна.

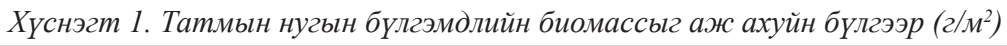

\begin{tabular}{|c|c|c|c|c|c|c|c|c|c|c|c|}
\hline \multirow{3}{*}{$\begin{array}{c}\text { Аж ахуйн } \\
\text { бүлэг }\end{array}$} & \multicolumn{5}{|c|}{ Хашсан талбай } & \multicolumn{6}{|c|}{ Хашааны гаднах талбай } \\
\hline & \multicolumn{2}{|c|}{2012} & \multicolumn{3}{|c|}{2013} & \multicolumn{3}{|c|}{2012} & \multicolumn{3}{|c|}{2013} \\
\hline & VII & VIII & VI & VII & VIII & VI & VII & VIII & VI & VII & VIII \\
\hline Үетэн & 37,87 & 26,99 & 31,17 & 39,19 & 18,70 & 15,77 & 46,22 & 24,77 & 17,6 & 22,27 & 29,51 \\
\hline Улалж & 16,91 & 6,55 & 19,06 & 24,39 & 30,86 & 16,7 & 24,9 & 12,9 & 20,17 & 20,36 & 21,50 \\
\hline Буурцагтан & 12,05 & 8,74 & 10,18 & 44,44 & 4,0 & 8,76 & 12,31 & 0,63 & 9,37 & 17,62 & 8,10 \\
\hline Алаг өвс & 107,2 & 45,2 & 58,5 & 85,4 & 49,1 & 67,07 & 99,28 & 42,07 & 73,37 & 118,05 & 44,61 \\
\hline Шарилж & 13,90 & 56,47 & 1,62 & 18,24 & 17,90 & 1,33 & 14,32 & 13,04 & 1,2 & 1,87 & 26,40 \\
\hline
\end{tabular}

Татмын нугын бүлгэмдлийн биомассын хөдлөлзүй цаг уураас хамаарч өөрчлөгдөх нь: Нуга нь гол горхи, усан сангийн эргэн тойрон чийг ихтэй газраар тархан ургасан олон наст өвслөг ургамал бүхий экосистемийн бүрэлдэхүүн хэсэг юм. Татмын үетэн алаг өвст нугын бүлгэмдлийн биомассыг центр га-д шилжүүлэн цаг уурын үзүүлэлтээс хамааруулан үзүүлэв (Хүснэгт 2). Сүүлийн хоёр жилийн хугацаанд хур тунадас олон жилийн дунджаас 2012 онд 48.6 мм-р, 2013 онд 68.6 мм-р их унасан бол, агаарын дундаж температур олон жилийн дунджаас 2012 онд $-1.2{ }^{\circ} \mathrm{C}, 2013$ онд $-0.2{ }^{\circ} \mathrm{C}$ хэмээр давж хүйтэрсэн, сэрүүн жил болов.

Хүснэгт 2. Татмын нугын бүлгэмдлийн ургаи ба экологийн зарим үзУүлэлт

\begin{tabular}{|c|c|c|c|c|c|c|c|c|c|c|c|}
\hline \multirow[b]{2}{*}{ № } & \multirow[b]{2}{*}{ Талбайн байршил } & \multirow[b]{2}{*}{ 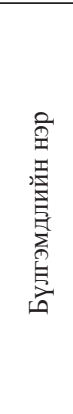 } & \multirow[b]{2}{*}{ 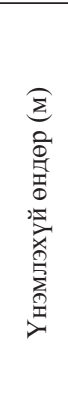 } & \multicolumn{2}{|c|}{$\begin{array}{c}\text { Олон } \\
\text { жилийн } \\
\text { дундаж }\end{array}$} & \multicolumn{3}{|c|}{2012} & \multicolumn{3}{|c|}{2013} \\
\hline & & & & 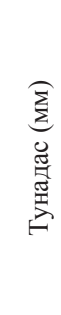 & 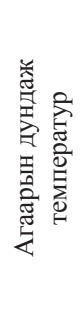 & 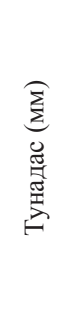 & 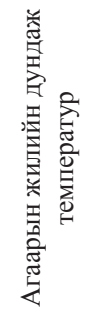 & 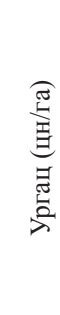 & 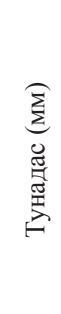 & 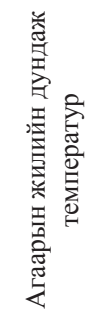 & 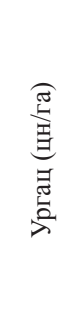 \\
\hline 1 & хашсан талбай & 卺 & 1439 & 267 & -2.7 & 316 & -3.9 & 55.3 & 336 & -2.9 & 50.3 \\
\hline 2 & $\begin{array}{c}\text { хашааны гаднах } \\
\text { талбай }\end{array}$ & $\underset{>}{\infty} 0$ & 1439 & 267 & -2.7 & 316 & -3.9 & 18.6 & 336 & -2.9 & 20.6 \\
\hline
\end{tabular}


Биомасс, цаг уурын хамаарлыг зураг 4 үзнэ үY.
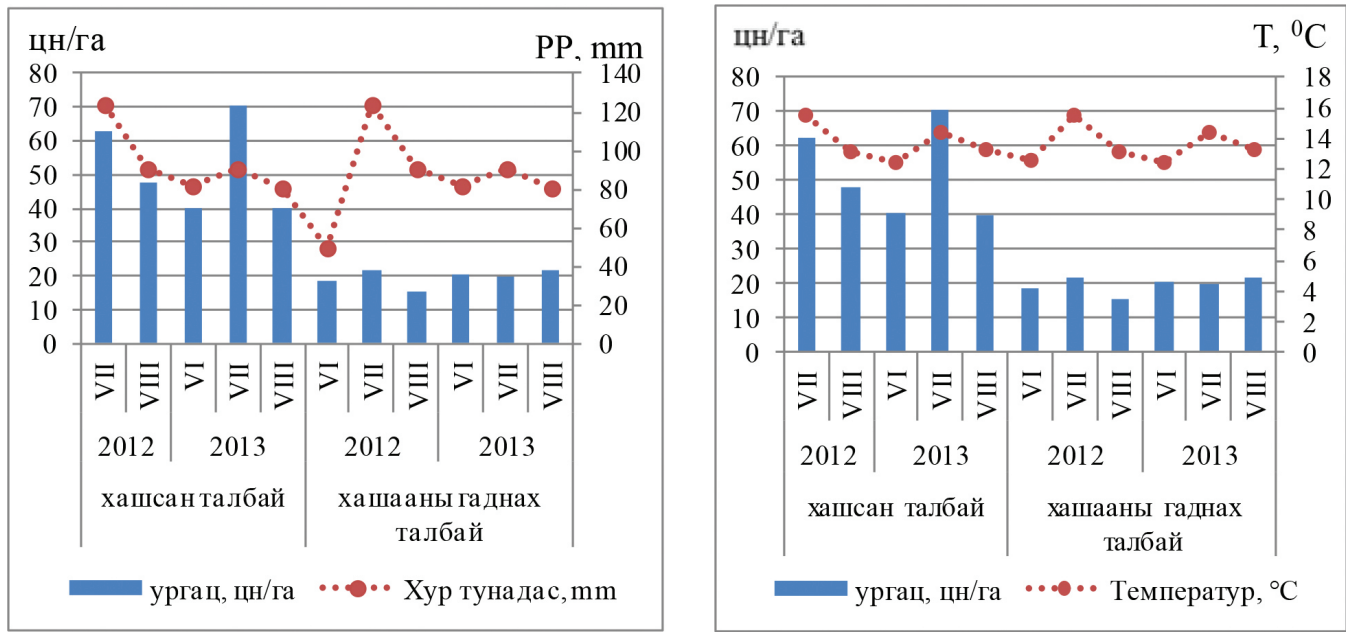

Зураг 4. Татмын нугын бүлгэмдлийн биомасс ияаг уурын хамаарал

(VI-VIII сарын агаарын дундаж температур, хур тунадас)

Татмын нугын хашсан болон хашааны гаднах бүлгэмдлийн биомасс, ургамал ургалтын үеийн (вегетацийн хугацааны) хур тунадас, агаарын дундаж температурын коррляцийн хамаарлыг авч үзвэл, хашсан бүлгэмдлийн биомасс VI-VIII сарын агаарын дундаж температураас $(\mathrm{R}=0.816)$ шууд, хашааны гаднах бүлгэмдлийнх $\quad(\mathrm{R}=0.47772)$ сул хамааралтай байна. Харин хашсан болон хашааны гаднах бүлгэмдлийн биомасс хур тунадаснаас $(\mathrm{R}=0.37096$ - 0.57672) сул хамааралтай байв. (Зураг 4). Тухайн бүлгэмдлийн ургацад хур тунадаснаас илүү агаарын дундаж температур чухал үүрэг гүйцэтгэж байна.

\section{ХЭЛЭЛЩУУЛЭГ:}

1.Ш.Дуламсүрэн (1994) улалжүетэн-алаг өвст нугын ургацын хөдлөлзүйг судалж ургац жил бүр харилцан адилгүй хэмжээтэй, бага температуртай жил тунадасны хэмжээ их байсан ч ургац бага хуримтлагддагийг тогтоожээ. Бидний татмын нугын үетэн-алаг өвст бүлгэмдэлд явуулсан ургацын судалгаагаар хур тунадаснаас илүҮ агаарын дундаж
Татмын нугын бүлгэмдлийн хашсан болон хашааны гаднах талбайн ургац хур тунадас их унахад (80-124 мм) буурах ба хамгийн бага ургац (хашсан талбайд 40.248 цн/га, хашааны гаднах талбайд 15.6-21.7 цн/га)-ыг бүрдүүлж байна.

Бүлгэмдлийн биомасс хуримтлалтанд цаг уурын нөлөөнөөс гадна мал хэт бэлчээрлэлт бүлгэмдлийг бүрдүүлэгч ургамлуудын биологи хөгжилд, улмаар ургамлыг дахин сэргэх чадваргүй түвшинд хүртэл доройтуулдагаараа илүү сөрөг нөлөөллийг үзүүлдэг. Энэ нь тухайн жилийн ногоон масс бүрдэлтэнд тодорхойлох үүрэг гүйцэтгэдэг. температур $(\mathrm{R}=0.816)$ ургац хуримтлагдахад тэргүүлэх үүрэгтэй оролцдог болон ойт хээрийн бүсийн ургамлын ургах үед чийг хангалттай их, температурын хүрэлцээ муу байдаг гэсэн үр дүнтэй тохирч байна.

2.Татмын нугын үетэн-алаг өвст бүлгэмдлийн зуны дээд ургац хуримтлагдах хугацаа нь бүлгэмдлийн цэцэглэлт болон үрлэлтийн үетэй давхцаж байна. Дээрх -58 - 
үр дүн нь В.Дүгэрмаа, Ж.Ундармаа (1994) нарын Орхон, Сэлэнгийн татмын нугад, Л.Жаргалсайханы (2014) Дорнод Монголы хээрт явуулсан судалгааны аль ч бүлгэмдэлд зуны дээд ургац бүрдэх үе нь зонхилогч ургамлуудын үр боловсрох үе шаттай тохирдог гэсэн дүгнэлттэй дүйцэж байв.

3.Н.Нарантуяагийн (1997) Дорнод Хэнтийн нугын бүлгэмдлүүдэд ашиглалтын горимын нөлөөг судалсан судалгааны хэт ашиглалтын нөлөөгөөр бүлгэмдлийн биомасс 2 дахин багасаж, малын иддэггүй ургамал зонхилдогоос түүний чанар мууддаг гэж дүгнэсэн нь бидний татмын нугад явуулсан судалгааны Үетэн-алаг өвст бүлгэмдлийн малын нөлөөнөөс хашиж хамгаалсан талбайн ургац 3 дахин нэмэгдэж, малын муу иддэг (Potentilla anserina,
Ranunculus acer, Artemisia leucophylla, A.medioxima) болон талхагдлын индикатор (Koeleria macrantha) зэрэг зүйлүүдийн биомасс, тэдгээрийн бүлгэмдэлд гүйцэтгэх үүрэг буурч байхад харин хашааны гаднах бүлгэмдэлд тэр нь ихэссэн байгаа үр дүнтэй тохиож байгаа юм.

Энэ үзүүлэлт нь өөрөө мал бэлчээрлэлтийн нөлөөнөөс бүлгэмдэл доройтож, түүний чанар муудаж буйг илэрхийлэгч үндсэн шалгуур үзүүлэлт болдог. Доройтсон бүлгэмдлий хашиж хамгаалахад байгалийн нугын бүлгэмдлийн үндсэн ургамлууд сэргэн ургах, бүлгэмдлийн биомасс нэмэгдэх, чанар сайжрах зэрэг эерэг үзүүлэлтүүд бий болж, их ашиглагдсан нугын бүлгэмдэл байгалийн аясаар нөхөн сэргэх боломж бүрддэг.

\section{ДҮГНЭЛТ}

1. Татмын үетэн-алаг өвст нугын бүлгэмдлийг мал бэлчээрлэлтийн нөлөөнөөс хашиж хамгаалахад бүлгэмдлийн биомасс 2 дахин нэмэгдэж, бүтэц сайжирдагаас нугын үндсэн зүйлүүд сэргэн ургаж, тэдгээрийн бүлгэмдэлд гүйцэтгэх үүрэг эрс дээшилдэг.

2.Татмын нугын бүлгэмдлийг хашиж хамгаалахад зуны дээд ургац нь 7-р сард, байнгын малын бэлчээрт ашиглагдаж буй бүлгэмдэлд 7, 8-р сард хуримтлагдаж, энэ нь ургамлын цэцэглэлт, үрлэлтийн хугацаатай давхцаж байв.

3.Татмын нугын бүлгэмдлийн зуны дээд биомасс хуримтлалтанд хур тунадаснаас илүү агаарын дундаж температур $(\mathrm{R}=0.816)$ тэргүүлэх үүрэгтэй байна.

\section{Аиигласан бутээлийн жагсаалт}

1. Бумжаа Д. 2002. Монгол орны ургамльн аймаг, ургамалжилт (оюутан, байгальорчинзуйн судлаачдад зориулсан гарын авлага) II хэсэг. Улаанбаатар.: МУИС-ийн хэвлэх үйлдвэр. -49-53.

2. ГомболҮҮдэв П., Начагдорж Л., Сарантуяа Г. 2010. Монгол орны уур амьсгальн өөрчлөлт, түҮний ирээдүйн төлөв. Төв Ази, Өмнөд Сибирийн шижилтийн экобүс нутгийн шим мандал дах экологийн үр дагавар. Улаанбаатар.: Бемби сан, 1: 41-44.

3. Дүгэрмаа В., Ундармаа Ж. 1994. Татмын нугын ургаи прогнозлох асуудалд, “Монгол орны ургамлын аймаг, ургамалжилтын судалгаа сүүлчийн 20 жилд” эрдэм шинжилгээний бага хурлын эмхэтгэл, Улаанбаатар.: -35.

4. Дуламсурэн Ш. 1980. Улалж-уетэн-алаг өвст нугын ургащын хөдлөлзүй, Бот.хүр.бүтээл, ШУА-ийн хэвлэх үйлдвэр, 4: 30-34.

5. Жаргалсайхан Л. 2014. Дорнод Монгольнн хээрийн зонхилох бүлгэмдлүҮдийн ургацын хөдлөлзуй, “Монгол орны ургамалжил-2014" эрдэм шинжилгээний бага хурлыгн эмхэтгэл. Улаанбаатар, Бемби сан, -107.

6. Өлзийхутаг, Н. 1985. Бүгд Найрамдах Монгол Ард Улсын хадлан, бэлчээр дэхь тэжээлийн ургамал таних бичиг. УБ: Улсын хэвлэлийн газар. -557. 
7. Монгол Улсын статистикийн эмхэтгэл, 2013

8. Нарантуяа Н., Мөнхзул О. 2013. Татмын нугын Үетэн-алаг өвст бүлгэмдэлд зонхилох зарим зуйл ургамльн иченопопуляцчийн судалгаа, ШУА-ийн мэдээ. Улаанбаатар, 01 (25). $-73-84$

9. Уур амьсгальн өөрчлөлтийн нөлөөлөл. 2005. -10.

10. Хосбаяр, Ч. 2012. Үетэн-алаг өвст нугын бүлгэмдэлд мал бэлчээрлэлтийн ҮзУүлэх нөлөө (Төв аймгийн Мөнгөнморьт сумын жичээгээр). Биологийн иинжлэх ухааны магистрын зэрэг горилсон бүтээл. МУИС. -56.

11. Хосбаяр Ч., Нарантуяа Н., Мөнхзул О. 2014. Татмылн нугын ургамалж-льлн мониторингийн судалгаа, “Монгол орны ургамалжил-2014” эрдэм иинжилгээний бага хурльн эмхэтгэл, Улаанбаатар, Бемби сан, -49-58.

12. Юнатов, А.А. 1950. Основнье черти растительного покрова Монгольс-кой Народной Республики “Труды Монг. Комис. АН СССР” выл. 39. М-Л. изв-во АН СССР, - 214.

13. Юнатов, А.А. 1968. Бүгд Найрамдах Монгол Ард Улсын Хадлан бэлчээр дэхь тэжээлийн ургамлууд. УБ: Хэвлэлийн комбинат. -310. 


\section{SUMMARY}

\section{CHANGING BIOMASS OF FLOOD MEADOW COMMUNITY UNDER INFLUENCE OF CLIMATE CHANGE}

Khosbayar $\mathrm{Ch}^{1}$, Narantuya $\mathrm{N}^{1}$

${ }^{\prime}$ - Institute of Botany, Mongolian academy of Sciences

The comparative biomass study began from 2012 in the grass-forb meadow community . Biomass study was compared between the fenced grazing and none fenced plant communities. The compared results due to years as follows: total biomass of fenced and none fenced communities in 2013 years with compare of the 2012 were increased 1,1-1.4 times. But total biomass of fenced community was increased 1,2 times than none fenced community. It depends with climate condition within the study years, Furthermore in 2013 rainfall more than $68,8 \mathrm{~mm}$, in $2012-48.6 \mathrm{~mm}$ precipitation from averages of many years, but average air temperatures are decreased on $-1,20 \mathrm{C}$ in $2012,-0,20 \mathrm{C}$ in 2013, This indicated that low air temperaturecoldness negatively influenced on biomass in meadow community, therefore air temperature is a dominant active factors on meadow biomass than precipitation. 